\title{
Normative Power Europe and Conflict Transformation
}

\author{
Thomas Diez, University of Birmingham, t.diez@bham.ac.uk;
}

Michelle Pace, University of Birmingham, m.pace@bham.ac.uk

\author{
Paper for Presentation at the 2007 EUSA Conference, Montreal, 17-19 May 2007
}

\begin{abstract}
The starting point for this paper is twofold. On the one hand, the authors have recently been involved in a study on European integration and border conflict transformation, which established conditions under which integration and association can have a desecuritising effect on border conflicts. One core condition was an image of the EU as a positive force in world politics. On the other hand, both authors have been involved in the debate on normative power Europe and have argued that this concept is better seen as a discursive self-construction imbuing the integration project with new force and establishing an EU identity against Others, rather than an objective analytical concept. In this paper, we explore the degree to which this self-construction of the EU is shared by others in international society, and in particular in conflict areas. Our basic hypothesis is that the EU's chances to act as a mediator, or to transform conflicts through association agreements and other forms of partnerships, largely depends on this acceptance of the notion of normative power Europe. The paper draws upon the cases of Cyprus and Israel/Palestine as examples. Its aim is to develop a theoretical framework with which the basic hypothesis can be studied, to discuss initial examples, and to draw out the political and normative consequences from the relationship between normative power Europe and conflict transformation, especially in light of our earlier criticism of the EU's self-construction.
\end{abstract}

Work in progress - incomplete references. Comments welcome.

\section{Introduction: Normative Power and Conflict Transformation}

That the EU is a novel type of actor in international politics is a widely accepted statement, although it is much more contested what exactly the features of this new actor are. Since Ian Manner's seminal article on this subject, the notion that the EU is a normative power has come to the centre of this debate (Manners 2002; see also Diez and Manners 2007). Manners sees the difference between the power of the EU and traditional, military forms of power in that the EU does not rely on military force or capabilities to achieve its aims, that its aims are linked to universal goods rather than being in the narrowly defined self-interest of the EU, and that it realises these goods by defining what should be accepted as "normal". Manners does not exclude the possibility that military power can at times reinforce normative power, but his central argument is that the EU as a normative power does not rely on military power to set the agenda and the standards of international politics. In contrast to earlier conceptualisations of its civilian power, it is not even economic means that are at the core of EU power. Instead, power becomes an effect of norm leadership and persuasion. 
The notion of "normative power Europe" has attracted both conceptual and empirical criticism. We have ourselves been involved in this debate (Diez 2005; Pace 2007a), where we have argued that "normative power Europe" is a discursive construction rather than an objective fact, and that the "power of normative power Europe" rests in the identity it provides for the EU and the changes it imposes on others, partly through its hegemonic status. Following our Foucauldian understanding of power, however, we argued that such a power is not necessarily a bad thing. Power, as Foucault reminds us, is first and foremost a productive force (Foucault 1981; 73). Whether the reality that is enabled by this power is a good or a bad one depends on the normative stance of the evaluator. In this paper, we explore the possibility that the self-construction of the EU as a normative power has positive effects on its potential influence to bring about positive conflict transformation, while at the same time it remains problematic in the Othering that it performs.

The idea that European integration and the EU itself are a positive force to resolve and transcend conflict is an old one, and we have explored this further in the context of another project (see Diez et al. 2006 and forthcoming). One of the findings of this project was that EU actors see themselves and the EU as a whole as a "force for good" in conflict situations, and indeed in world politics generally speaking (Pace forthcoming). This tallies with our earlier argument that "normative power Europe" is first and foremost a discourse in which EU actors themselves construct themselves as "model citizens".

Does this self-construction of EU actors enable them to play a positive role in conflict transformation, or is it rather a hindrance? If it does play a positive role, should one on this basis not happily partake in this discourse, as Manners (2006b) suggests in his defence? These are the questions that we will address in this paper. We begin by setting out the core concepts that we use and the theoretical debates we draw upon (section 2). In section 3, we provide evidence of EU actors portraying themselves as a 'force for good' in conflict situations and link this to the "normative power Europe" debate. We then proceed to assess the impact of this self-portrayal in concrete conflict situations, where we draw primarily on our work on Cyprus and the Middle East (section 4). Finally, we argue that while there are instances where the "normative power Europe" discourse does allow EU actors to have a positive influence in conflict situations, this should not lead us to uncritically accept this self-representation. Instead, as critical analysts, we must always point to the hegemonic constructions that come with normative power, even if it appears to be a force for good.

\section{A Theoretical Framework}

Third party interventions in conflicts are the subject of extensive studies in conflict research, which has produced a number of arguments about the conditions for success of mediation in particular. Among these are both factors that characterise the conflict or the conflict parties and factors that relate to the mediator. Zartman (1989), for instance, has argued that resolution attempts are most likely to be successful if a conflict is "ripe" in that it has reached a "hurting" stalemate that the parties cannot maintain without huge cost, and where neither party sees itself as likely to achieve victory. As far as the 
mediator is concerned, the literature suggests that such actors should ideally be powerful, respected and impartial, although not necessarily in a combination of all of these qualities (Smith 1994; Siniver 2006: 809). Before exploring these further in relation to "normative power", let us first address several other aspects of this literature that are of relevance to our argument.

Firstly, the literature is at odds about when exactly a mediation attempt can be counted as successful. Some regard the conclusion of a peace agreement as sufficient; others focus on broader changes of attitude (Siniver 2006: 808). We side with the latter. While this makes the measurement of success more difficult, the mere signing of an agreement is not sufficient to count as a mediation success unless this agreement turns out to be a milestone towards lasting peace. To achieve lasting peace, however, the incompatibilities at the heart of a conflict need to be transformed, which requires broader societal changes in terms of the definition of identities and interests. We also, however, maintain that success does not have to be characterised by the disappearance of conflict. Rather, conflict will remain in any society - the crucial question is how conflict is dealt with, and how other conflict parties are seen within society. We therefore speak of conflict transformation as the ultimate aim of third party intervention, which indicates that if such intervention is successful, conflict will persist, but the way actors see themselves and relate to each other will have been transformed to such an extent that they will not resort to violent means, and ideally will change their identity so that conflict is fundamentally altered (see Diez et al. 2006: 565-6). The "measure" that we apply to assess transformation is the degree to which actors make their claims in the form of securitising moves, i.e. the extent to which they invoke the other party or parties as an existential threat to legitimise their actions, and ultimately violence (Diez et al. 2006: 566-7; on securitisation, see Buzan et al. 1998: 21-4; Wæver 1995 as well as Diez and Huysmans 2007).

The literature secondly focuses on mediation through a particular actor. We use the broader concept of intervention here, by which we do not mean military intervention but any involvement of a third party in a conflict, which can include support for NonGovernmental Organisations (NGOs), conflict resolution workshops, and other such activities aimed at conflict transformation but not necessarily fitting the category of "mediation". Furthermore, while the literature usually distinguishes between mediating actors and institutional contexts, the EU plays a role both as a classical third party actor and as an institutional context insofar as it has been using integration and association as means to achieve conflict transformation (see Diez et al. 2006; Higashino 2004). The effect of the institutional context that the EU provides on conflicts is often described as a form of Europeanisation (Coppetiers et al. 2004).

It is intriguing in this context that Manners developed his concept of normative power explicitly in contrast to the question of whether the EU is an actor or not (add reference). Normative power does not presuppose an actor that consciously exerts this power; it can also emanate from an institutional structure (in the EU context, the acquis communautaire), or from a broad discourse associated with the EU. However, there is an ambiguity in the way that Manners uses the concept of power. On the one hand, power, 
as just outlined, is the property of a relationship. On the other hand, power is also the property of the entity that is associated with the more powerful position in the relationship. To that extent, the EU both exerts normative power and is a normative power.

As indicated in the introduction, most of the literature has now engaged in a dispute about whether the characterisation of the EU as a normative power in this sense is accurate. Leaving aside whether this is a question that can be settled on the basis of empirical observation (for a discussion, see Diez 2005: 625-6), we want to argue that the far more interesting question in our context is to what extent the EU is constructed as a normative power, or to what extent the EU is seen as setting standards and leading by example rather than using military or other force in order to influence other actors. This construction takes place both outside the EU as well as within the EU, where there is a widespread self-representation as a "force for good", especially in the Commission and the Parliament, but also in the Council, as we will show in the next section (see also Pace 2007a and forthcoming).

On this basis, the question becomes whether this construction of the EU as a normative power makes it more likely that the EU is successful when intervening in conflicts in the sense of being able to contribute to conflict transformation with a decreasing presence of securitising moves, where intervention is broadly defined to include mediation efforts as well as less formal engagements with conflict parties. The construction of the EU as a normative power can be related to the EU as an actor or to the EU as an institutional presence in international politics. Normative power in this sense becomes part of the reputation that is seen as one core factor influencing the success of third party interventions.

We can now consider the different possibilities for the impact of the construction of the EU as a normative power on conflict transformation:

(1) The construction is not shared by conflict parties, in which case we would expect no or a negative effect if the EU's role in international politics is ridiculed/challenged.

(2) The construction is shared by conflict parties but the norms espoused by the EU are not, in which case we would also expect no or a negative effect if the EU's role in international politics is ridiculed/challenged.

(3) The construction is shared by conflict parties, in which case we would expect that they are inclined to accept the EU's role in the conflict, and would be more likely to follow EU advice or take the integration experience as an example.

(4) The construction is shared only by some conflict parties, in which case we would expect at least a positive influence over the behaviour of this party.

(5) The construction is shared at least by some conflict parties, but at least one conflict party uses EU norms to strengthen its own position, with the consequence of reinforcing rather than transforming conflict. 
(6) The construction is shared by at least some conflict parties, but there are other aspects of the EU reputation that make the normative power reference less effective.

In the remainder of this paper, we will first establish the self-representation of EU actors as a normative power, and then provide some illustrations for how our framework works out empirically. We need to stress that we do not offer a comprehensive study that would sufficiently test these hypotheses, which would require a larger study than we can pursue here, and which would at this stage need further reflections on operationalisation.

\section{The EU's self-representation as a "force for good"i}

It is our contention here that EU actors project an image of the EU as a facilitator in the transformation of border conflicts through projections of its 'force for good'. The power of EU actors' self-description of the EU as a 'force for good' is, in turn, based on an assumption that through international socialization - a process driven by the logics of appropriateness and arguing - conflict parties can be induced to accept the internalization of international norms. In this way, conflict parties are led to adopt the constitutive rules of the EU. In order to understand more fully the extent to which this self-representation occurs, we need to unpack the EU's composition in terms of its key actors: the Council, the Commission and the European Parliament as well as the instruments at hand for these actors to construct an image of the EU as a force for good.

When EU instruments for mediating in conflict situations are restricted to association and therefore stop short of an offer for full EU membership (as in the case of Israel and Palestine), EU actors resort to emphasizing to conflict parties the importance of implementing association and cooperation agreements signed by the latter with the EU as these processes bring conflict parties closer to the EU's image as a 'force for good'. The EU's active role in the transformation of border conflicts is thus constructed through providing association as a way forward for conflict parties to emulate the cooperation model on which the EU is founded. Through association, EU actors thereby endeavour to create a discursive framework that generates similar dynamics as integration, but falls short of sharing the EU institutions and involvement in decision making. This discursive framework however can potentially turn the projection of the EU as a 'force for good' into a self-fulfilling prophecy, allowing conflict parties to claim what they have been promised (as in the case of Cyprus' EU membership in the case of integration) or to take the opportunities offered through association to negotiate better terms for their relation with the EU. Through the acquis communautaire (membership), as well as the acquis of association (through the Barcelona Process or Euro-Mediterranean Partnership for Mediterranean partners) conflict parties are encouraged to either join the 'club' or to participate as close outsiders through association. These mechanisms enable EU actors to further their ideals of the EU as a 'force for good'.

Thus, the "force for good" discursive framework offers political leaders in conflict cases opportunities to legitimise domestic policies aimed at diminishing conflicts, from which the constructive impact of re-defining political identities may follow. Moreover, EU 
actors' self-description of the EU as a 'force for good' produces a platform for activists, civil society organisations and NGOs to use rhetorical and symbolic tools, including shaming tactics, to get their political leaders to comply with the values, norms and ideals that EU actors advance (as for instance the Cyprus case illustrates). Through the two case studies we drawn upon here, we aim to investigate the potential for the sharing of these ideals through their adoption by conflict parties. But before we do that, a look at the key $\mathrm{EU}$ actors constructing the EU as a force for good is called for.

Within the Council, the Special Representative (SR) acts as a facilitator, a consensus builder and a focal reference point between the EU and parties to a conflict through almost permanent presence on the ground. In the Middle East case, the EUSR provides active support to actions and initiatives leading to a final settlement of the conflict and contributes to the implementation of international agreements reached between the parties and engages with them in the event of non-compliance with these agreements. He/she also reports on possibilities for EU engagement and on the best way of pursuing EU initiatives and ongoing Middle East Peace Process (MEPP)-related EU efforts. The SR is thereby an example of a specific EU actor working to reproduce what the EU stands for in its role as an external actor in border conflict situations. As one interviewee put it:

Does the EU have a different approach in conflicts? The Solana 2003 security strategy report was the first time the EU presented its view. According to this strategy, we do not need an invitation to be involved. Solving the Middle East (ME) conflict is vital to our interests. Europe is a political concept. As regards the EU's various instruments ... CFSP seized to be just about working groups when the first Special Representative was appointed. The Venice Declaration in the 1980s was the first CFSP act. The ME is a laboratory for CFSP. The EU is present in the ME. The efficiency of our instruments can be improved of course ... but the EU is there as a political actor. The invention of the Quartet came from here (Council) ... the appointment of a Prime Minister in the PA to circumvent US/Israeli policy was invented here ...The Road Map was invented here ...We have been providing the impetus ... to circumvent the views of the EU being not a player but a banker ... Barcelona (the EMP) is the first real step towards reconciliation in the region ... we provided a forum for Arabs and Israelis ... we believe that if the conflict is not solved we cannot solve other regional problems ... the ME provides fertile ground for the Council, with the Commission and the EP, to have a role. We share communication on a daily basis. The $\mathrm{ME}$ is fertile ground for common EU institutional endeavours. Moratinos (former EUSR) was the path finder. Overall our efforts are positive. ii $^{\text {. }}$

Moreover, each EU member state also has the opportunity to leave its own imprint on EU policy towards border conflicts when it holds the Presidency. The way border conflict issues are dealt with in the EU depend on the particular Member State Presidency's priorities - which may in turn shift (albeit slightly) the priorities of the Council for those six months. ${ }^{\text {iii }}$ 
Furthermore, in cases of conflict within the Mediterranean, the Council and High Representative for Common Foreign and Security Policy are in a strategic position to constructing the EU's role as a 'force for good' through the Common Strategy on the Mediterranean acquis (Attiná 2001: 282). This contrasts with the institutional structure designed in Barcelona in November 1995 (when the Euro-Mediterranean Partnership or EMP was launched) and other official documents of the EMP through which the Commission was given a stronger strategic role in producing and reproducing the narrative of the EU as a 'force for good'. As the guardian of the integration and association processes, the Commission emerges as endorsing the discourse of the EU as a 'force for good' more forcefully than perhaps any other EU actor in the context of border conflicts.

The Commission's endorsement of the discourse about the EU as a 'force for good' is further reinforced through the presence of over 120 of its delegations and offices around the world which act as its mouthpiece in cases of conflict on the ground:

On the ground we are supported by Commission delegations. Our strength in all situations is where we manage to reduce the intensity of conflicts through indirect inducements - not through areas directly related to conflict. Modesty is important here: we can achieve much more especially in cases of long standing conflicts .. We don't (at the Commission) have the competence to aim for direct issues, maybe through Solana's Security Strategy, in political form, we may in the future ... iv

The force for good self-representation is not so obvious when we look at the European Parliament. In fact, members of the European Parliament (MEPs) do not easily buy into the discourse of the EU as a 'force for good'. For instance, in a report on the European Neighbourhood Policy, MEPs emphasise that this policy - which is aimed at avoiding the emergence of new, dividing borders after the EU's enlargement of May 2004 - should not be an instrument of 'settling for the status quo but of committing the European Union to support the aspirations of the peoples of our neighbouring countries to full political freedom, with democracy and justice ...' including the stricter use of political conditionality (European Parliament 2005). This does not, however, mean that MEPs do not play a role in producing a self-understanding of the EU as a 'force for good' - witness the reference to political freedom etc in the same quotation.

As can be concluded from this section, the workings, productions and reproductions of the EU as a 'force for good' narrative are more apparent within the Commission but also in the Council and Parliament. Having looked at how this construction takes place within the EU, we now move to examine how it plays out 'outside' the EU. 


\section{The Impact of the EU's self-representation on conflict transformation}

\subsection{The case of Cyprus}

In the case of Cyprus, the construction of the EU as a normative power has played a predominant role in the influence the $\mathrm{EU}$ has had on the conflict in the island, although not always a positive one. A core justification for starting membership negotiations with Cyprus was that these would have a "catalytic effect" on the conflict (see Diez 2002a), eventually leading to conflict transformation and the unification of the island. Partly, this catalytic effect was to come about because membership was seen to be in the interest of ordinary Turkish Cypriots and would force Turkey to change its policy if it did not want to jeopardise its own membership prospects. However, there was also the expectation that membership would bring with it the hope for a redefinition of identities on the island, as well as the respect of fundamental rights of all Cypriots, whether Greek- or TurkishCypriot, so that the atrocities of previous decades could not be repeated (Tocci 2005; Diez 2002b). It is in this latter sense that the EU was supposed to be important as a normative power.

This view was initially advocated by the Greek Cypriots, but soon shared by many in the EU institutions. That Cyprus was accepted as a membership candidate in 1994, despite earlier hesitations by the Commission who had initially insisted on a resolution to the conflict, is often put down to a package deal with Greece, which also involved the end of Greece vetoing the customs union with Turkey. However, there is also a normative power aspect to the story. A core part of the normative power construction is the observance of international law - the EU as a "good international citizen". Until recently, however, the international jurisdiction from Security Council resolutions to European Court of Human Rights rulings was firmly and unequivocally on the side of the Greek Cypriots, and gave all, or at least most of the blame for the conflict and the partition of the island to Turkey. Under these circumstances, the argument that the Greek Cypriots should not be penalised for Turkey's violation of international law became a forceful one that was hard to counter by those who would have preferred to stick to the condition of resolution before membership. This makes clear that the self-representation of the EU as a normative power is not only enabling, but also restricting the EU in its engagement with conflict parties, and indeed more widely, as similar effects have been shown in relation to EU enlargement in a broader sense (Fierke and Wiener 2001; Schimmelfennig 2001).

Indeed, this aspect of the normative power construction has made the EU problematic as an independent third party from the start. In addition, the fact that Greece has already been a member state when Cyprus applied for membership and the British colonial history of the island also contributed to the EU's problematic involvement in the conflict. This is one of the reasons why it has never attempted to be a mediator in the classic sense of the term and left this task explicitly to the United Nations (see Richmond 2002). Even when, in line with the normative power construction, the EU provided funds for bicommunal projects such as the Nicosia Master Plan, it did so through the United Nations Development Programme rather than directly, until Cyprus became part of the EU. 
These circumstances also led the Turkish Cypriot leadership under Rauf Denktash to reject the EU membership bid as "enosis [unification with Greece] through the back door". Denktash did not see the EU as a "force for good", at least not in the Cyprus context. Many Greek Cypriots however unashamedly saw the prospect of EU membership as a tactic to strengthen their political position in the conflict, which had reached a "comfortable" rather than a "hurting" stalemate. From the start, therefore, hypothesis (5) is applicable to Cyprus, and we would have expected the reinforcement of the conflict rather than decreasing securitisation.

On an official level, this expectation held initially, and there were threats Ref? of fully integrating northern Cyprus into Turkey if the south became part of the EU. Yet one of the mistakes in much of the literature on Cyprus was to underestimate the dissatisfaction among Turkish Cypriots with their leadership. While the mass demonstrations in 2001 were sparked by a banking crisis and anger about economic measures imposed by Turkey, the EU became a central reference point in them to articulate claims against the Denktash regime in the attempt to construct a 'non-exclusive Turkish Cypriot identity within the EU' (Lacher and Kaymak 2005: 159) In that sense, EU normative power played a crucial role in shaping the political landscape among Turkish Cypriots, not as a catalyst but as a framework to draw upon once the banking crisis catalysed the situation. Ultimately, the developments led to the opening of the border between the two sides, the moderate Mehmet Ali Talat taking over first as Prime Minister, then as President, and to the Turkish Cypriots, in contrast to the Greek Cypriots, accepting the Annan Plan for a resolution and the foundation of a United Cyprus Republic.

There is now a widespread understanding of the EU as a normative power in Cyprus albeit contested surely?. However, hypothesis (5) still applies, as "Europeanisation" in the dominant Greek-Cypriot view is taken to mean the unrestricted implementation of the four freedoms (of goods, services, capital and labour) and the notion that a divided island would not be in the spirit of the integration project (see Demetriou forthcoming; Gürel and Özersay 2006: 366). The construction of the EU as a normative power therefore makes EU involvement problematic because one conflict party uses this construction to reinforce its own position. As in the acceptance of the bid for membership, this makes it difficult for other EU actors to argue against the Greek Cypriot position, now strengthened by the fact that as a member state, Cyprus can obstruct and veto policies that it sees as interfering with its sovereignty, and has the option of direct recourse to the European Court of Justice. This is problematic in itself, but also because it leads to disillusionment among Turkish Cypriots with the idea of the EU as a "force for good". Symptomatic are the desperate attempts by the northern Cypriot Eastern Mediterranean University to be allowed to take part in the Bologna Process. While the Republic of Cyprus is vetoing such a step as recognising an "illegal entity", the University invokes European norms of equality and a right to education to get access (Güven 2007).

These disputes also demonstrate one further problematic aspect of the construction of the EU as a normative power: The norms that the EU is supposed to espouse are not necessarily in line with each other, and depending on the context can be seen as 
competing. In Cyprus, the norm of cooperation and peace recommends action different from the norm of sticking to international law, or the Greek-Cypriot interpretation of the acquis. This is surely a situation of special circumstances, but it does indicate that normative power may be self-defeating if it contains norms that are seen as contradictory.

All in all, the Cypriot picture as far as the impact of the normative power construction is concerned is mixed. The fact that one conflict party has used the construction to strengthen its position over the other party has not made it ineffective. Indeed, as we have shown, the notion of clear-cut conflict parties is itself misguided, and EU normative power played a crucial role in the transformations of the political landscape in the north. One cannot therefore say that there has been a reinforcement of the conflict, as hypothesis (5) would suggest, but while there have been many changes in conflict behaviour, there has also not been a transformation to the extent that one could see EU engagement in present circumstances as successful, and in line with hypotheses (5) and (3), we would only expect this to happen once there is a change in the Greek Cypriot position, assuming that by that time, the Turkish Cypriots have not changed their minds again.

\subsection{The case of Israel/Palestine}

During 2005, the EU, together with the US, issued a series of annunciations encouraging the Palestinian President Mahmoud Abbas to hold elections in the belief that the obstacles facing the peace process would become unblocked and that Fatah (the main secular-nationalist faction of the PLO) would win another endorsement from the Palestinian electorate to continue ruling the PA. The EU, as well as the so-called international community, had a specific belief that the transformation of the conflict in the Middle East lay in the export of a blueprint for democracy in Palestine (a proto-state and an experiment in limited autonomy. Milton-Edwards, 2007; Pace, 2007b and Sadiki 2004).

Despite these statements, emphasising the importance of free, fair and transparent elections, the results of the January 2006 election have been considered by the EU and 'the international community' as unacceptable in terms of the wider linkage to the Middle East Peace Process. Although the EU sent its own mission to observe these elections which were declared as fair, free and transparent (although how an election process can be 'fair' under occupation may be disputed) - the organisation reacted by freezing direct aid to the PA, since the elected Hamas was put on the EU's black list of outlawed terrorist organizations. ${ }^{\mathrm{V}}$ During the same month, the Quartet issued a statement announcing a series of conditions on an internal arrangement for governance in Palestine: recognition of Israel, cessation of violence and acceptance of previous agreements, as conditions for assistance to the Palestinian people - through the PA - on the Hamas government.

What the EU failed to acknowledge was the fact that the discourse of democracy it has been attempting to export to the Middle East and North Africa region, and more specifically to Palestine in this case, was also falling on the ears of the region's Islamists 
including the Palestinian Hamas movement. The EU's reaction to the January 2006 election was thus interpreted in the Middle East as a sign of the EU ignoring the democratic expression of the Palestinian people (even though it had made democracy one of the conditions for its help) and depriving many Palestinians of their livelihood. Therefore, although Palestinians appeared to take their first steps toward pluralism, the EU's reactions to the electoral victory by Hamas stand in stark contrast to EU actors' self-construction of the EU as a normative power in the region and its associated mediation and conflict transformation agenda for the Middle East (Pace, 2007b). With the rising force of modern Islamism in the southern Mediterranean neighbourhood the misreading of the EU's efforts at exporting democracy to these societies has therefore come at a very high price, both in relation to the MEPP and the nature of how the politics and societies of the MENA are developing - a price the EU and the international community, have, so far, not been willing to pay.

As a way of breaking the position adopted by the Quartet members in March 2006 (when they severed relations with the Hamas-dominated PA over a demand on the conditions set), in February 2007, Fatah and Hamas (the main protagonists in the Palestinian experiment of democratic governance) agreed to a new accord on power-sharing and political relations. The ensuing 'Mecca Agreement' highlighted the formation of a national unity government (NUG) and President Abbas insisted that the Palestinians had now met the conditions of the Quartet. However, the EU's response to Mecca was once again - at least for most Palestinian observers - disappointing. Although the EU welcomed the formation of the national unity government, they announced that they would have no contact with Hamas ministers in the government.

Since its democratic election to power, Hamas has had to deal with a number of internal factors of governance including their lack of capacity in 'doing governance' ${ }^{\text {vi }}$ Hamas had won the election on a platform of 'Change and Reform' and their determination to 'serve the Palestinian people' by ensuring their rights. But they had no previous experience to fall back on when they found themselves in a position of power within the PA. Given the EU's previous efforts at encouraging good governance in the southern Mediterranean neighbouring partners (not least through all its EMP as well as its ENP instruments) it is ironic that such a window of opportunity for the EU's discourse of a 'force for good' was not taken up through the option of training Hamas elected officials in governance capacity-building!

The other party to the conflict, Israel, together with the United States, reacted with caution to the Mecca agreement claiming that any new government must reject terror, recognise Israel and honour past accords, but stopped short of making clear whether it was satisfied by the deal. It was however hoped that the deal brokered in Mecca would end weeks of factional unrest in the West Bank and Gaza Strip. Although the EU did not lift the aid sanctions against the Palestinians, the issue of contact with non-Hamas members of the government was a departure from the Israeli and US position regarding the national unity government (the US and Israel decided to boycott the NUG in its entirety). Perhaps because of its discourse as a force for good, the EU thus emerges as slightly more flexible in its response in this context than either Israel (a party to the 
conflict) or the US (a key external actor in the conflict). But from the Hamas viewpoint, it seems that their expectations from the EU's image as a force for good was a serious miscalculation in that they had entered into the NUG thinking that the EU would eventually be more lenient and cooperate with the new government. Norway, a non-EU European state, was the only European country which sought engagement (rather than isolation) with the Hamas leader and prime minister, Ismail Haniyeh. Raymond Johansen, Norway's deputy foreign minister, called on other governments to follow suit. Although it is an EEA member, as a non-EU member Norway's calls for engagement by the international community with the NUG and all its Ministers fell on deaf ears.

In refusing to engage the political leadership of Hamas (this could be mainly due to the fact that Germany, as the current holder of the rotating EU Presidency and as a key ally of the other party to the conflict, Israel, has the final word in what the EU actually does in this context), the EU refused to test the impact of its 'force for good' rhetoric as well as the simultaneous claims the Islamic movement makes to be both a negotiator for Palestinian rights and liberator of Palestinians (norms that the EU - albeit rhetorically upholds very dearly). In such a limited vision of normative power, important forms of social exclusion are overlooked and the careful analysis and engagement with the conditions of possibility of what it means in practice to be a 'force for good' is placed to one side.

Therefore, hypothesis (6) is applicable to the Israel/Palestine case, where although EU actors' construction as a force for good is shared by at least some conflict parties, other aspects of the EU's reputation make the normative power reference less effective and which in turn has a negative effect on possibilities for conflict transformation due to the contradictions in the EU's rhetoric as a force for good on the one hand and its actual praxis on the other.

\section{Condition or Contradiction? A Critical Assessment}

The EU is not only discussed as, it also sees its self as a normative power, a "force for good", in international politics. If accepted by other actors, we argued in this paper, this should put it in a good position to intervene in conflicts to transform them so that violent action no longer dominates or is prevented in the future, and that conflict issues are dealt with not in terms of security but under "normal" democratic procedures. However, the two cases that we drew upon to illustrate our argument paint a different picture. In both of them, the conflict has not taken a clearly positive turn even though the EU is involved, albeit to various degrees. It seems then that EU normative power in conflict situations, at least as long as they are not formally and unambiguously part of the integration process, remains largely an unrealised potential. In our two cases, this has as much to do with the EU itself and how it interacts with the conflict parties, often in contrast to its selfconstruction as a "force for good", as it has with the way the conflict parties see the EU.

To the extent that there have been transformations in these two conflicts, and that one can arguably link them to EU involvement, the impact has been ambiguous rather than 
leading to positive conflict transformation in the form of de-securitisation. In the Cyprus case in particular, the normative power of the EU was effective after the banking crisis that led to a change in political leadership and the acceptance of the Annan Plan. However, this normative power is fading to the extent that northern Cyprus is hardly closer to the EU than it was before the accession of the Republic of Cyprus and the Annan Plan referenda. Indeed, as we have seen, EU normative power has also enabled forces on the Greek-Cypriot side to strengthen their claims and to articulate the conflict with further securitising moves.

We therefore found that in our cases, our initial propositions (5) and (6) prevailed: While some, and at times all of the conflict parties accepted the construction of the EU as a normative power, they either did so to strengthen their own position, or, as in the case of Israel-Palestine, they also held other views of the EU that counter-acted and overrode any potential positive impact flowing from the normative power construct. Of course, our cases had an initial illustrative purpose and cannot count as a systematic evaluation of our argument, but we suggest that similar findings will emerge from other studies: EU normative power is not simply able to shape conceptions of what is seen as normal; its effectiveness rather relies on the extent to which other actors accept the role that EU actors themselves project for themselves into international politics.

The failure to act consistently in the Israel/Palestine case in particular also reinforces our previous argument that much of the normative power discourse is not about an "objective" analysis of EU behaviour but rather about the construction of an EU identity. While Manners (2006a: 168, 2006b) sees this as a positive political move of the original normative power argument, we would like to point to the dangers that this involves. Such an identity construction blinds actors from their own failings and deficiencies both in internal affairs as well as in their engagement with others. To the extent that it enables practices that undermine the construction itself, the notion of an identity of the EU as a normative power not only has problematic consequences, but may also be self-defeating.

All of this does not deny the potential that there is in the normative power discourse for a positive role that the EU can play in conflict transformation. The current evidence, however, provides a much more ambiguous and patchy picture. As with other aspects of normative power Europe, such power will only be a positive force to the extent that others accept it, and if it is, not merely about telling others how great the EU is.

\section{References}

Attiná, Fulvio (2001) ‘Conclusions: Partnership Building' in F. Attiná and S. Stavridis (eds.), The Barcelona Process and Euro-Mediterranean Issues from Stuttgart to Marseille. (Milan: Dott. A Giuffrè Editore). Buzan, Barry; Ole Wæver and Jaap de Wilde (1998) Security: A New Framework for Analysis (Boulder, CO: Lynne Rienner).

Chehab, Zaki (2007) Inside Hamas. The Untold Story of Militants, Martyrs and Spies (London and New York: I.B. Tauris). 
Coppetiers, Bruno et al. (2004) Europeanization and Conflict Resolution: Case Studies

from the European Periphery (Gent: Academia Press).

Demetriou, Olga (forthcoming) 'Catalysis, catachresis: the EU's impact on the Cyprus conflict' in Diez et al. (forthcoming).

Diez, Thomas (2002a) 'Last exit to paradise? The European Union, the Cyprus conflict and the problematic "catalytic effect"', in Thomas Diez (ed), The European Union and the Cyprus Conflict: Modern Conflict, Postmodern Union (Manchester: Manchester University Press), 139-62.

Diez, Thomas (2002b) 'Why the EU can nonetheless be good for Cyprus', Journal on Ethnopolitics and Minority Issues in Europe 2 (2), http://www.ecmi.de/jemie/download/Focus2-2002_Diez.pdf.

Diez, Thomas (2005) 'Constructing the self and changing others: reconsidering “normative power Europe”' Millennium: Journal of International Studies 33 (3), 613-36.

Diez, Thomas and Jef Huysmans (2007) 'Securitizations and desecuritizations: the politics of exception and the politics of unease', manuscript under review.

Diez, Thomas and Ian Manners (2007) 'Reflecting on normative power Europe', in Felix Berenskoetter and Michael J. Williams (eds) Power in World Politics (London: Routledge), forthcoming.

Diez, Thomas; Stephan Stetter and Mathias Albert (2006) 'The European Union and border conflicts: the transformative power of integration' International Organization 60 (3), 563-93.

Diez, Thomas; Mathias Albert and Stephan Stetter (eds) (forthcoming) The European Union and Border Conflicts (Cambridge: Cambridge University Press).

European Parliament (2005) Report on the European Neighbourhood Policy. Foreign Affairs Committee, Rapporteur Charles Tannock, Document A6-0399/2005, 7 December. Fierke, Karin M. and Antje Wiener (2001) 'Constructing institutional interests: EU and NATO enlargement', in Thomas Christiansen, Knud Erik Jørgensen and Antje Wiener (eds) The Social Construction of Europe (London: Sage), 121-39.

Foucault, Michel (1981) 'The Order of Discourse', trans. Ian McLeod, in R. Young (Ed.) Untying the Text. (London: Routledge \& Kegan Paul).

Gürel, Ayla and Kudret Özersay (2006) 'Cyprus and the politics of property' Mediterranean Politics 11 (3), 349-69.

Güven, Halil (2007) Update on efforts to end educational isolations imposed on North Cyprus Universities, e-mail correspondence, 6 March 2007.

Higashino, Atsuko (2004) 'For the sake of 'peace and security'? The role of security in the European Union enlargement eastwards' Cooperation and Conflict 39 (4), 347-68.

Hroub, Khaled (2006) Hamas. A Beginner's Guide (London: Pluto Press).

Lacher, Hannes and Erol Kaymak (2005) 'Transforming identities: beyond the politics of non-settlement in north Cyprus’ Mediterranean Politics 10 (2), 147-66.

Levitt, Matthew (2006) Hamas. Politics, Charity, and Terrorism in the Service of Jihad (New Haven and London: Yale University Press).

Manners, Ian (2002) 'Normative power Europe: a contradiction in terms?' Journal of Common Market Studies 40 (2), 235-58.

Manners, Ian (2006a) 'The European Union as a normative power: a response to Thomas Diez’ Millennium: Journal of International Studies 35 (1), 167-180. 
Manners, Ian (2006b) 'What is normative about the normative power of the European Union in world politics?', Paper presented at the $47^{\text {th }}$ ISA convention, San Diego, 22 March 2006.

Milton-Edwards, Beverley (2007) 'Hamas, government and the challenge for democratic reform'. Paper presented at a workshop on Europe's Legacy? From colonialism to democracy promotion: the case of the Mediterranean. Centre for Contemporary Middle East Studies, University of Southern Denmark, Odense, Denmark, 21-22 Apr.

Pace, Michelle (2006) The Politics of Regional Identity: Meddling with the Mediterranean (London: Routledge).

Pace, Michelle (2007a) 'The Construction of EU Normative Power' Journal of Common Market Studies (September issue, forthcoming).

Pace, Michelle (2007b) 'Paradoxes and Contradictions in EU democracy promotion in the Mediterranean: the limits of EU normative power'. Paper presented at a workshop on Europe's Legacy? From colonialism to democracy promotion: the case of the Mediterranean. Centre for Contemporary Middle East Studies, University of Southern Denmark, Odense, Denmark, 21-22 Apr.

Pace, Michelle (forthcoming) 'The EU as a "force for good” in border conflict cases?' in Diez et al. (eds) (forthcoming).

Richmond, Oliver (2002) 'The multiple dimensions of international peacemaking: UN and EU involvement in the Cyprus conflict', Thomas Diez (ed), The European Union and the Cyprus Conflict: Modern Conflict, Postmodern Union (Manchester: Manchester University Press), 117-36.

Sadiki, Larbi (2004) The Search For Arab Democracy. Discourse and CounterDiscourses (London: Hurst \& Company).

Schimmelfenning, Frank (2001) 'The community trap: liberal norms, rhetorical action and the eastern enlargement of the European Union' International Organization 55 (1), 47-80.

Siniver, Asaf (2006) 'Power, impartiality and timing: three hypotheses on third party mediation in the Middle East' Political Studies 54 (4), 806-26.

Smith, James D. (2004) 'Mediator impartiality: banishing the Chimera' Journal of Peace Research 31 (4), 445-50.

Tamimi, Azzam (2007) Hamas. Unwritten Chapters (London: Hurst \& Company).

Tocci, Nathalie (2005) EU Accession Dynamics and Conflict Resolution: Catalysing Peace or Consolidating Partition in Cyprus? (London: Ashgate).

Wæver, Ole (1995) 'Securitization and Desecuritization’, in Ronnie D. Lipschutz (ed.)

On Security (New York: Columbia University Press), 46-86.

Zartman, I. William (1989) Ripe for Resolution: Conflict and Intervention in Africa; updated edition (New York: Oxford University Press).

i This section draws upon Pace in Diez et al, forthcoming.

ii Interview, Council of the European Union (Brussels, 20 January 2004).

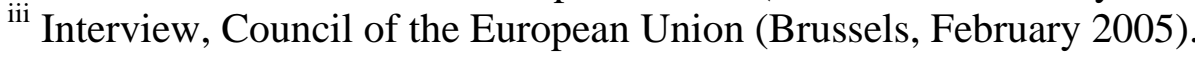

iv Interview, European Commission (Brussels, 21 January 2004). 
${ }^{\mathrm{v}}$ Hamas had also received much international condemnation for using suicide attacks to pursue its resistance strategy. In the eyes of the EU, Hamas challenges the notion of a democratic political party.

${ }^{v i}$ Hamas's decision to take part in the 2006 elections had a profound impact on the nature of the movement as well as on the Palestinian political scene and on the peace process at large. At the level of its internal composition, participation in the election was perceived as a step towards politicizing the movement - at the expense of its well-known militarism. See Chehab 2007; Hroub 2006; Levitt 2006 and Tamimi 2007 for more on this. 